\title{
Pengembangan Pembelajaran Berbasis Multimedia Interaktif Menggunakan Adobe Flash Cs.6 dalam Pembelajaran Matematika Pada Kelas X Materi Pokok Pertidaksamaan Satu Variabel
}

\author{
Nanang Nabhar Fakhri Auliya \\ Institut Islam Negeri Kudus \\ nanangnabhar@gmail.com
}

\begin{abstract}
The problem studied in this research are learning in the classroom tend to be monotonous because of the lack of media-based interactive multimedia learning mathematics are expected to increase academic achievement. The purpose of this study is to plan and produce a media product based interactive multimedia learning mathematics in the material inequalities of one variable and determine the feasibility of mathematics learning CD.

The studies of this research is that the development aims to produce software adobe flash matematikamenggunakan learning competency standards CS. 6 inequalities one variable in class X Madrasah Aliyah Sunan Pandanaran and know the quality of the CD is based on the assessment of mathematics learning and teaching material experts, media experts and 61 students of class $\mathrm{X}$.

Development begins with content standards followed by analysis by collecting reference media, then draft the media, and make the CD learning. Learning CDs that have been made consulted with experts and specialists multimedia materials, inputs/ suggestions then used to revise the learning $\mathrm{CD}$. The results of the revision was tested to the students in two classes. Learning CD contains competency standards with the material inequalities of one variable linear inequalities, quadratic inequalities, fractional inequalities, inequalities of the root and absolute value inequalities.

Research has succeeded in developing mathematics learning CD that have quality Very Good (SB) according to the judgment of 61 students of class X MA Sunan Pandanaran with the percentage of $83.67 \%$ making learning $\mathrm{CD}$ fit for use as a medium of learning.
\end{abstract}

Keywords: Learning Media, Adobe Flash CS.6, Inequality One Variable

\section{ABSTRAK}

Masalah yang dikaji dalam penelitian ini adalah pembelajaran di kelas yang cenderung monoton karena kurangnya media pembelajaran matematika berbasis multimedia interaktif yang diharapkan dapat meningkatkan prestasi belajar. Adapun tujuan penelitian ini adalah merencanakan dan memproduksi suatu produk media pembelajaran matematika berbasis multimedia interaktif pada materi pertidaksamaan satu variabel dan mengetahui kelayakan dari CD pembelajaran matematika.

Penelitian ini merupakan penilitian pengembangan yang bertujuan untuk menghasilkan produk pembelajaran matematikamenggunakan software adobe flash CS.5 standar kompetensi pertidaksamaan satu variabel pada kelas X Madrasah Aliyah Sunan Pandanaran dan mengetahui kualitas CD pembelajaran matematika tersebut berdasarkan penilaian ahli materi dan pembelajaran, ahli media dan 61 siswa kelas X.

Pengembangan ini dimulai dengan cara analisis standar isi dilanjutkan dengan mengumpulkan referensi media, kemudian menyusun rancangan media, dan membuat CD pembelajaran. CD pembelajaran yang telah dibuat dikonsultasikan kepada ahli materi dan ahli multimedia, masukan/saran selanjutnya digunakan untuk merevisi CD pembelajaran. Hasil revisi tersebut diujikan kepada siswa di 2 kelas. CD prmbelajaran ini memuat standar kompetensi pertidaksamaan satu variabel dengan materi pertidaksamaan liniear, pertidaksamaan kuadrat, pertidaksamaan pecahan, pertidaksamaan bentuk akar dan pertidaksamaan harga mutlak.

Penelitian telah berhasil mengembangkan CD pembelajaran matematika yang mempunyai kualitas Sangat Baik (SB) menurut penilaian dari 61 siswa kelas X MA Sunan Pandanaran dengan persentase $83,67 \%$ sehingga CD pembelajaran layak digunakan sebagai media pembelajaran.

Kata kunci : Media Pembelajaran, Adobe Flash CS.6, Pertidaksamaan Satu Variabel. 


\section{Pendahuluan}

Telah kita ketahui ketahui bersama, bahwa matematika adalah raja dari segala bidang ilmu. Hal ini tidak berlebihan, karena matematika memiliki sifat yang universal dengan segala bentuk pembelajarannya. Hal ini menunjukkan bahwa matematika akan selalu dipakai dalam berbagai aspek dalam kehidupan manusia, terutama dalam bidang teknologi. Dengan semakin pesat pertumbuhan ilmu teknologi sekarang ini maka semakin menunjukkan bahwa manusia tidak akan bisa hidup tanpa matematika sehingga perlu ditingkatkan kualitas ilmu matematika.

Di Indonesia, kualitas ilmu matematikanya tergolong rendah. Hal ini dapat dilihat dari prestasi belajar matematika siswa di ajang internasional.Berdasarkan data Trends in International Mathematics and Science Study (TIMSS) pada tahun 2011, Indonesia berada di peringkat bawah yaitu peringkat ke-38 dari 42 negara dengan skor rata-rata 386, sedangkan skor rata-rata international 500 (Timss and pirls, 2011: 3). Pada tahun 2015 peringkat itu tidak membaik, Indonesia berada pada ke-45 dari 50 negara Data TIMSS tersebut tidak jauh beda dengan data dari Programme for International Student Assessment (PISA) tahun 2012 yang menunjukkan Indonesia mendapat peringkat sangat rendah yaitu peringkat ke-64 dari 65 negara dengan skor rata-rata 375, sedangkan skor rata-rata international 500 (OECD, 2014:5).

Salah satu pokok bahasan berdaya serap rendah adalah pokok bahasan Pertidaksamaan satu variabel. Berdasarkan data dari Pusat Penilaian Pendidikan, daya serap siswa MA (Madrasah Aliyah)Sunan Pandanaran Sleman terhadap pokok bahasan pertidaksamaan dengan indikator menyelesaikan masalah yang berkaitan dengan pertidaksamaan satu variabel pada tahun 2014/2015 hanya sebesar 48,32\%.Hal ini mengindikasikan bahwa siswa MA Sunan Pandanaran Sleman mengalami kesulitan dalam memahami materi pertidaksamaan, khususnya pada indikator tersebut. Oleh sebab itu, dibutuhkan upaya yang dapat membantu meningkatakan prestasi belajar matematika siswa khususnya pada pokok bahasan pertidaksamaan.

Menurut Rachmawati dalam seminar hasil TIMSS 2015, 66\% mengaku menyukai pelajaran matematika dan jumlah tersebut lebih besar dari rerata internasional yaitu sebesar 45\%. Akan tetapi siswa Indonesia masih kurang percaya diri dalam menjawab sebuah soal, hail ini dikarenakan penguasaan materi yang kurang maksimal. Kesulitan dalam memahami dan mempelajari matematika disebabkan karena objek matematika yang abstrak, tidak nyata dan hanya dapat diwujudkan dalam bentuk simbol dan model, itulah mengapa matematika sulit untuk dipahami oleh para siswa. Itu dapat dirasakan siswa ketika belajar materi pertidaksamaan satu variabel. Oleh karena itu dibutuhkan suatu inovasi dalam permbelajaran, salah satuya adalah penggunaan media.

Media adalah segala alat fisik yang dapat menyajikan pesan serta merangsang siswa untuk belajar (SadimanArief S, 2007: 6). Siswa perlu adanya media untuk mempelajari 
matematika sehingga ke abstrakan matematika dapat mereka pelajari dengan mudah. "Pemakaian media pembelajaran dalam proses belajar mengajar dapat membangkitkan keinginan dan minat yang baru, membangkitkan motivasi, dan rangsangan kegiatan belajar bahkan membawa pengaruh-pengaruh psikologis terhadap siswa" (ArsyadAzhar, 2010 : 15).

Siswa pada awalnya paham dengan materi yang diajarkan tapi ketika pulang atau soalnya diganti siswa kesulitan dalam mengerjakan soal, itulah mengapa diperlukannya mediasebagai alat bantu mengajar guru. Alat bantu yang dipakai adalah alat bantu visual yang dapat memberikan pengalaman kongkret, motivasi belajar serta mempertinggi daya serap dan retensi siswa. Namun sayang, karena waktu, tempat atau kurangnya pemahaman tentang penggunaan dan pembuatan media pembelajaran sehingga belum optimalnya penggunaan media pembelajaran. Salah satu media yang sekarang dapat dikembangkan adalah pemanfaatan teknologi komputer.

Dengan media pembelajaran menggunakan komputer ini diharapkan akan dapat membantu siswa untuk memahami materi matematika. Dengan menggunakan komputer ini diharapkan pembelajaran akan semakin menarik dan variatif.

Perangkat lunak atau software yag sangat mendukung sebagai media pembelajaran dalam matematika, salah satunya adalah Adobe Flash CS.6. Software ini dipilih karena Adobe Flash CS.6adalah sebuah perangkat lunak pembuat animasi, dimana merupakan suatu yang sangat menarik dan banyak orang yang menyukai animasi. Adobe Flash CS.6 mempunyai banyak kelebihan dalam penggunaannya, khususnya dalam penyampaian materi pelajaran pada siswa sehingga siswa lebih tertarik untuk mempelajarinya. Kelebihan tersebut diantaranya adalah gambar, animasi, dan suara yang mempunyai daya tarik tersendiri dan lebih memudahkan mempelajari materi pelajaran. Dengan beberapa kelebihan Adobe Flash CS.6sangat mendukung dalam pengembangan media pembalajaran matematika berbentuk multimedia interaktif.

Berdasarkan uraian maka diketahui bahwa media pembelajaran matematika penting dalam membantu dan memudahkan dalam memahami materi pelajaran matematika. Karena pentingnya media pembelajaran matematika sehingga peneliti mempunyai keinginan untuk melakukan penelitian dengan judul "Pengembangan Pembelajaran Berbasis Multimedia Interaktif Menggunakan Adobe Flash CS.6 Dalam Pembelajaran Matematika Pada Siswa Kelas X Materi Pokok Pertidaksamaan Satu Variabel”.

\section{PEMBATASAN MASALAH}

Sehubung dengan keterbatasan waktu, biaya dan kemampuan dari peneliti serta agar tidak terjadi kerancuan atau kesalahan terhadap pemahaman permasalahan yang penulis teliti, maka penulis membatasi permasalahan sehingga tujuan yang diharapkan dapat tercapai. Dalam hal ini pembatasan masalahnya yaitu pada media pembelajaran matematika 
pada materi pokok pertidaksamaan satu variabel. Serta program pengembangan media ini dibuat dengan menggunakan software Adobe Flash CS.6.

\section{RUMUSAN MASALAH}

Bedasarkan latar belakang masalah dan batasan masalah yang telah diuraikan di atas, maka dapat dirumuskan masalah yaitu:

1. Bagaimanakah merencanakan dan membuat atau memproduksi media pembelajaran matematika dengan Adobe Flash CS.6 pada materi pokok pertidaksamaan satu variabel?

2. Bagaimanakah kelayakan media pembelajaran matematika dalam mendukung pembelajaran matematika pada materi pokok pertidaksamaan satu variabel yang dibuat?

\section{TUJUAN PENELITIAN}

Tujuan yang ingin dicapai dalam penelitian ini yaitu untuk

1. Merencanakan media pembelajaran interaktif

2. Membuat media pembelajaran interaktif

3. Mengetahui kelayakan dan kesusaian produk media pembelajaran matematika dalam mendukung pembelajaran matematika pada materi pokok pertidaksamaan satu variabel.

\section{SPESIFIKASI PRODUK YANG DIKEMBANGKAN}

Untuk memecahkan masalah diatas, maka peneliti akan menerapkan pembelajaran berbasis multimedia interaktif menggunakan Adobe Flash CS.6dalam pembelajaran matematika. Produk yang dihasilkan berupa sebuah CD pembelajaran interaktif, dimana dalam pembuatan CD pembelajaran interaktif akan menggunakan softwareAdobe Flash CS.6. SoftwareAdobe Flash CS.6ini adalah sebuah perangkat lunak pembuat animasi yang mudah untuk digunakan. Di dalam akan memuat pembelajarn yang menarik menggunakan animasi sehingga siswa lebih mudah untuk menguasai materi pelajaran.

Adapun spesifikasi dalam CD pembelajaran interaktif adalah sebagai berikut:

1. Pembahasan materi

Dalam pembahasan materi, penjelasan atau pemaparan materi akan dibuat dengan animasi menarik sehingga siswa merasa termotivasi dalam belajar dan menguasai akan materi yang di bahas.

2. Latihan soal

Setelah siswa menguasai materi yang dibahas, siswa diberikan soal berupa pilihan ganda. Sehingga siswa mengetahui tingkat kepahaman mereka.

\section{KAJIAN TEORI}


Kata media berasal dari bahasa latin dan merupakan bentuk jamak dari kata medium yang secara harfiah berarti perantara atau pengantar. Medòë adalah perantara atau pengantar pesan dari pengirim ke penerima pesan (SadimanArief S, 2007: 6). Dalam bahasa Arab, media disebut "wasail” bentuk jama' dari "wasilah" yakni sinonim al wasth yang berarti "tengah". Jadi dapat disimpulkan bahwa media pembelajaran adalah segala sesuatu yang dapat menyalurkan pesan, dapat merangsang fikiran, perasaan, dan kemauan peserta didik sehingga dapat mendorong terciptanya proses belajar pada diri peserta didik.

Media pembelajaran interaktif adalah suatu sistem penyampaian pengajaran yang menyajikan materi video rekaman dengan pengendalian komputer kepada penonton (siswa) yang tidak hanya mendengar dan melihat video dan suara, tetapi juga memberikan respon yang aktif, dan respon itu yang menentukan kecepatan dan sekuensi penyajian (Seels \& Glasgow dalam Arsyad, 2002:36).

Rob Philips dalam buku Arsyad menjelaskan "makna interaktif sebagai suatu proses pemberdayaan siswa unutk mengendalikan lingkungan belajar." Interaktif disini tidak terlepas dari adanya hubungan timbal balik antara komputer dan pengguna melalui alat-alat perantara seperti monitor, keyboard, mouse dan sebagainya. Jadi dengan menggunakan multimedia interaktif diharapkan siswa dapat mempelajari materi dengan mudah dan mandiri.

Adobe Flashadalah sebuah program yang digunakan untuk membuat gambar vektor maupun animasi gambar tersebut. Hasil dari Adobe Flash sendiri ada yang berupa file extension.swf dan dapat didigunakan di web yang telah dipasangi Adobe Flash Player. Bahasa yang digunakan dalam program ini adalah ActionScript.

Adobe Flash merupakan sebuah program yang didesain khusus oleh Adobe dan program aplikasi standar authoring tool professional yang digunakan untuk membuat animasi dan bitmap yang sangat menarik untuk keperluan pembangunan situs web yang interaktif dan dinamis. Flash didesain dengan kemampuan untuk membuat animasi 2 dimensi yang handal dan ringan sehingga flash banyak digunakan untuk membangun dan memberikan efek animasi pada website, CD Interaktif dan yang lainnya. Selain itu aplikasi ini juga dapat digunakan untuk membuat animasi logo, movie, game, pembuatan navigasi pada situs web, tombol animasi, banner, menu interaktif, interaktif form isian, e-card, screen saver dan pembuatan aplikasi-aplikasi web lainnya.

Dalam Flash, terdapat teknik-teknik membuat animasi, fasilitas action script, filter, custom easing dan dapat memasukkan video lengkap dengan fasilitas playback FLV. Keunggulan yang dimiliki oleh Flash ini adalah ia mampu diberikan sedikit code pemograman baik yang berjalan sendiri untuk mengatur animasi yang ada didalamnya atau digunakan untuk berkomunikasi dengan program lain seperti HTML, PHP, dan Database dengan pendekatan XML, dapat dikolaborasikan dengan web, karena mempunyai keunggulan antara lain kecil dalam ukuran file outputnya. 
Belajar merupakan proses manusia untuk mencapai berbagai macam kompetensi, ketrampilan, dan sikap. Belajar dimulai sejak manusia lahir sampai akhir hayat. Kemampuan manusia untuk belajar merupakan karakteristik penting yang membedakan manusia dengan makhluk hidup lainnya. Dengan demikian, belajar tidak hanya dipahami sebagai aktivitas yang dilakukan oleh pelajar saja. Tapi lebih dari itu, pengertian belajar itu sangat luas dan tidak hanya sebagai kegiatan di bangku sekolah saja.

Dalam Kamus Besar Bahasa Indonesia, secara etimologis belajar memiliki arti berusaha memperoleh kepandaian atau ilmu. Definisi ini memiliki pengertian bahwa belajar adalah sebuah kegiatan untuk mencapai kepandaian atau ilmu. Sedangkan secara terminologis definisi belajar menurut Cronbach (1954), belajar yang terbaik adalah melalui pengalaman. Dengan pengalaman tersebut pelajar menggunakan seluruh pancaindranya. Menurut Morgan dan kawan-kawan (1986), yang menyatakan bahwa belajar adalah perubahan tingkah laku yang relative tetap dan terjadi sebagai hasil latihan atau pengalaman (Baharuddin, 2007:13-14).

Belajar matematika berbeda dengan belajar mata pelajaran yang lain. Karena dalam belajar matematika itu diperlukan suatu prasyarat yaitu berupa kesinambungan antara mata pelajaran satu dengan yang lainya. Jika prasyarat itu tidak dikuasai atau salah satu pokok bahasan tidak menguasai maka siswa akan mengalami kesulitan dalam memahami pokok bahasan berikutnya. Oleh karena itu belajar matematika adalah proses yang aktif untuk mempelajari dan memahami tentang konsep-konsep abstrak yang diberi symbol tertentu dan disusun secara hirarkis.

\section{METODE PENELITIAN}

Penelitian ini merupakan penelitian pengembangan (Research and Development). Metode penelitian dan pengembangan atau dalam bahasa Inggrisnya Research and Development adalah metode penelitian yang digunakan untuk menghasilkan produk tertentu, dan menguji keefektifan produk tersebut. Teknik pengambilan data menggunakan angket yang digunakan untuk mengevaluasi dan mengetahui tingkat kelayakan media, angket terdiri dari 3 jenis yaitu: (1) Angket untuk uji media (2) Angket untuk uji materi (3) Angket penggunaan.

Desain uji coba pengembangan ini sebelum diujicobakan, produk dievaluasi oleh beberapa ahli. Uji coba lapangan dilakukan setelah mendapat validasi dari ahli dan masukan yang diperoleh dijadikan sebagai dasar untuk merevisi produk. Tujuan dari uji coba adalah untuk mengetahui kelayakan dari media pembelajaran yang dikembangkan. Setelah media pembelajaran dinyatakan layak, barulah dilakukan uji lapangan yang melibatkan siswa kelas. Penelitian ini dilaksanakan di kelas X MA Sunan Pandanaran Sleman Yogyakarta. 
Teknis analisis data dengan menghitung jumlah skor tiap butir pertanyaan. Adapun tingkat kelayakan media secara keseluruhan dihitung dengan menggunakan rumus

$$
\mathrm{P}=\frac{\mathrm{S}}{\mathrm{S}_{\mathrm{m}}} \times 100 \%
$$

dimana

$\mathrm{P}=$ Tingkat kelayakan media $(\%)$

$\mathrm{S}=$ Jumlah skor total yang diperoleh

$\mathrm{S}_{\mathrm{m}}=$ Jumlah skor total maksimum

Dari persentase yang telah diperoleh kemudian ditransformasikan ke dalam kalimat yang bersifat kualitatif dengan interval nilai, yang dapat dilihat pada Tabel 1 .

Tabel 1. Transformasi Persentase ke dalam Kalimat

\begin{tabular}{|l|c|c|}
\hline No & $\begin{array}{c}\text { Rentang (i) } \\
\text { kuantitatif }\end{array}$ & $\begin{array}{c}\text { Kategori } \\
\text { kualitatif }\end{array}$ \\
\hline 1 & $\bar{X}>80 \%$ & Sangat Baik \\
\hline 2 & $66,67 \%<\bar{X} \leq 80 \%$ & Baik \\
\hline 3 & $53,34 \%<\bar{X} \leq 66,67 \%$ & Cukup \\
\hline 4 & $40 \%<\bar{X} \leq 53,34 \%$ & Kurang \\
\hline 5 & $\bar{X} \leq 40 \%$ & Sangat Kurang \\
\hline
\end{tabular}

\section{HASIL PENELITIAN DAN PEMBAHASAN}

Penelitian ini telah berhasil mengembangkan CD pembelajaran matematika menggunakan softwareAdobe Flash CS.6pada siswa kelas X pada pokok bahasan pertidaksamaan satu variabel dengan materi pertidaksamaan linear, pertidaksamaan kuadrat, pertidaksaman pecahan, pertidaksamaan bentuk akar dan pertidaksamaan harga mutlak. Dalam CD pembelajaran terdapat materi, latihan soal dan evaluasi.

Pembuatan media adalah proses menterjemahkan desain pada tampilan yang sebenarnya. Hasil dari pembuatan masing-masing desain adalah sebagai berikut:

1. Tampilan Pembuka dan Judul

Tampilan Pembuka dan judul berisi pembuka media, lambang UAD, judul media pembelajaran dan nama penyusun. Tampilan Pembuka juga terdapat tombol mulai untuk melanjutkan kebagian berikutnya.Tampilan pembuka dapat dilihat pada Gambar 1: 


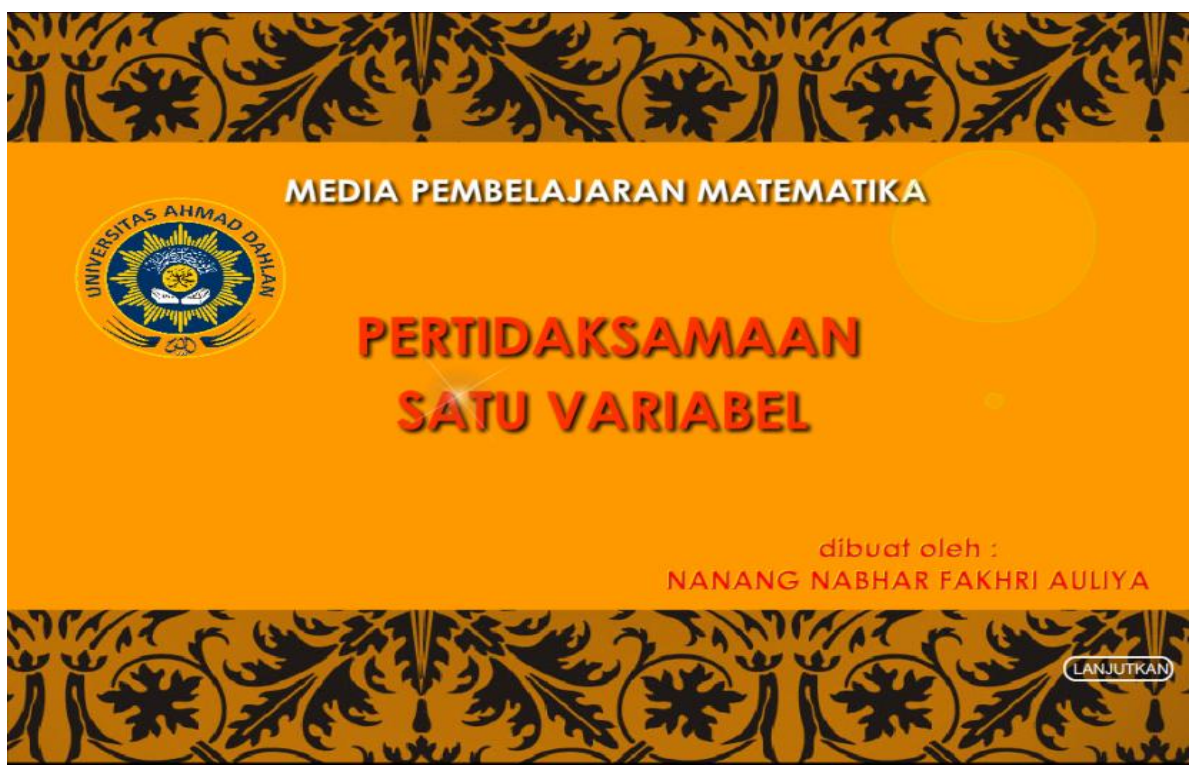

Gambar 1 Bagian Pembukadan Judul

2. Tampilan menu

Bagian utama terdapat sembilan tombol pilihan yaitu home, standar kompetensi,materi, evaluasi, profil, lanjut, maximize, minimize dan keluar.Ketika pengguna memilih tombol home akan berisi ucapan selamat datang dalam media pembelajaran. Ketika pengguna memilih tombol lanjut maka akan muncul petunjuk penggunaan media pembelajaran. Ketika pengguna memilih tombol standar kompetensi makaakan muncul standar kompetensi, kompetensi dasar dan tujuan. Ketika pengguna memilih tombol materi maka akan memunculkan bagian materi. Ketika pengguna memilih tombol evaluasi maka akan memunculkan bagian evaluasi. Ketika pengguna memilih tombol profil maka akan mucul profil pembuat media pembelajaran (peneliti). Ketika pengguna memilih tombol maximize maka ukuran media pembelajaran akan membesar, tombol minimize maka ukuran media pembelajaran akan mengecil, dan tombol keluar digunakan ketika pengguna ingin mengakhiri media pembelajaran.Tampilan menu utama dapat dilihat pada Gambar 2 :

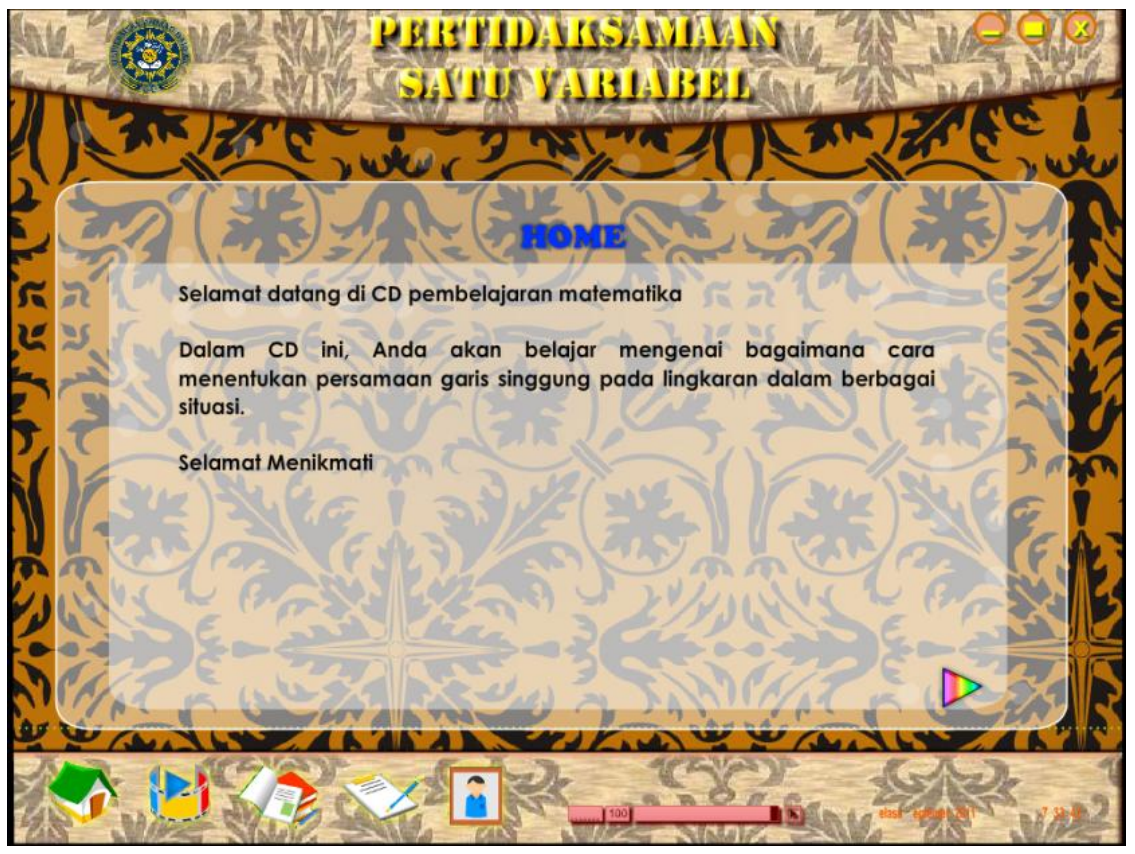

Gambar 2 Tampilan Menu 
3. Tampilan materi

Menu materi adalah bagian yang menampilakn tombol- tombol pilihan materi yang terdiri dari materi pertidaksamaan linear, pertidaksamaan kuadrat, pertidaksamaan pecahan, pertidaksamaan bentuk akardan pertidaksamaan harga mutlak. Ketika pengguna memilih materi yang diinginkan maka akan muncul isi materi yang dipilih tadi.Tampilan materi dapat dilihat pada Gambar 3:

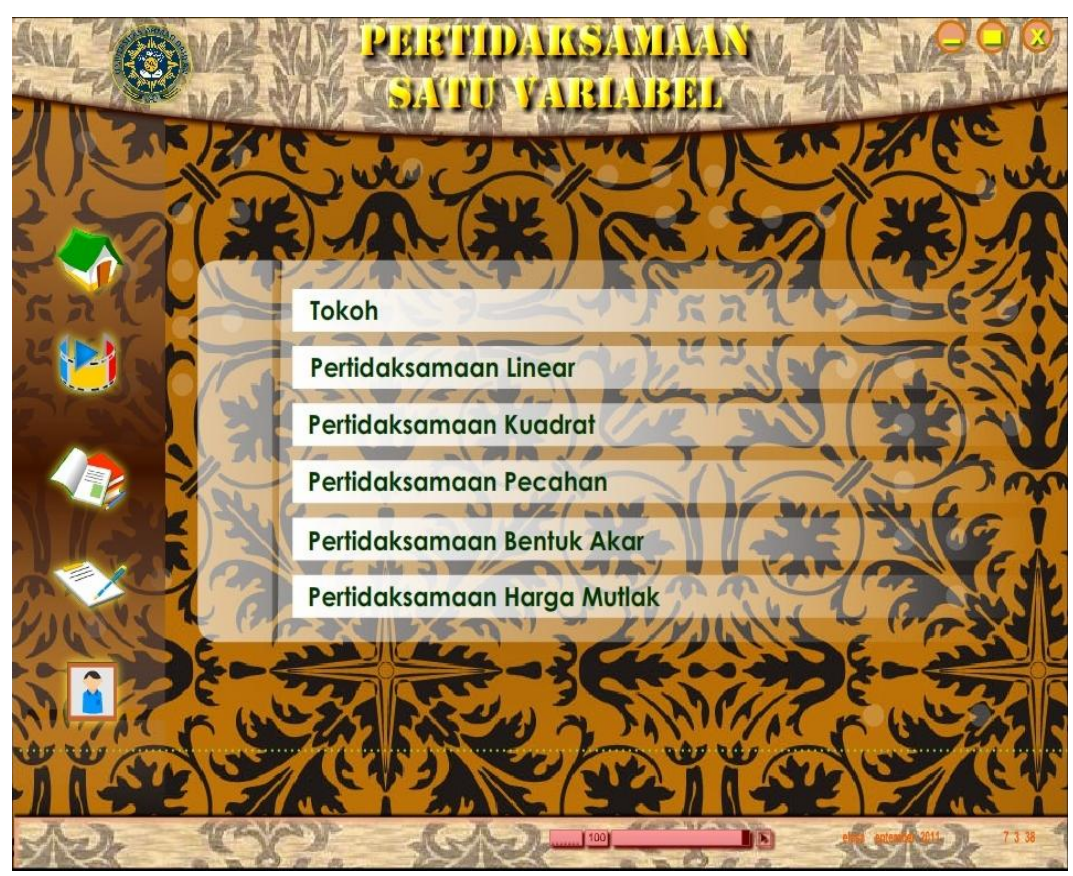

Gambar 4 Menu Materi

4. Tampilan evaluasi

Setelah pengguna memilih menu evaluasi akan muncul bagian evaluasi yang berisi soalpilihan ganda yang di jawab dengan meng-klik pada salah satu pilihan jawaban. Tampilan evaluasi dapat dilihat pada Gambar 5:

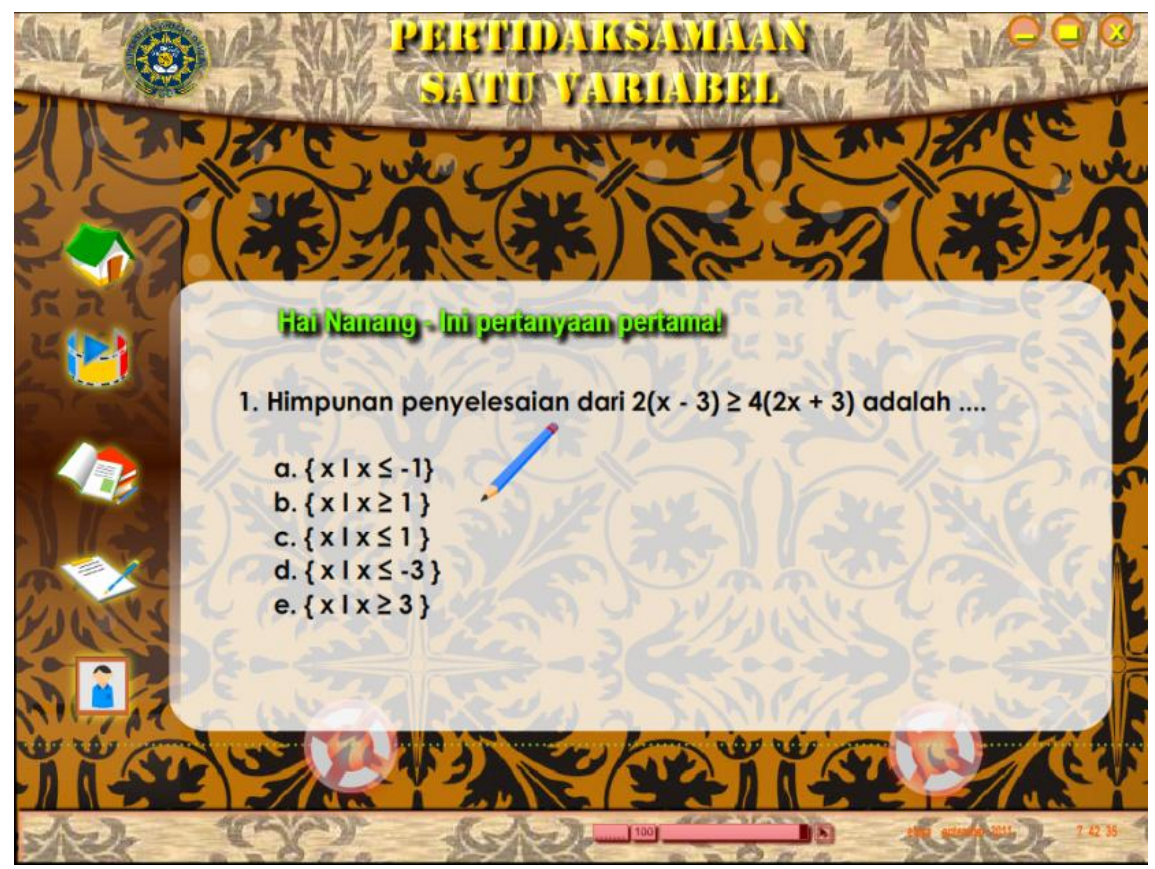

Gambar 5 Tampilan evaluasi

Berdasarkan pengisian angket yang telah diisi oleh ahli media, ahli materi dan pengguna (siswa) yang dapat dilihat pada Tabel 1, Tabel 2, Tabel 3. 
1. Hasil perhitungan kelayakan oleh ahli media.

Tabel 2. Hasil Perhitungan Kelayakan oleh Ahli Media

\begin{tabular}{|l|c|c|c|c|c|}
\hline No & Penilai & $\begin{array}{c}\text { Jumlah } \\
\text { skor }\end{array}$ & $\begin{array}{c}\text { Skor yang } \\
\text { diharapakan }\end{array}$ & $\begin{array}{c}\text { Persentase } \\
\text { Rata-rata }\end{array}$ & Kategori \\
\hline 1. & Penilai ke-1 & 66 & 80 & $82,50 \%$ & Sangat Baik \\
\hline 2. & Penilai ke-2 & 71 & 80 & $88,75 \%$ & Sangat Baik \\
\hline 3. & Penilai ke-3 & 68 & 80 & $85,00 \%$ & Sangat Baik \\
\hline \multicolumn{2}{|c|}{ Jumlah } & 209 & 240 & $87,08 \%$ & Sangat Baik \\
\hline
\end{tabular}

Dari Tabel 2 terlihat bahwa presentase kelayakan oleh ahli media yaitu pada penilai ke-1 sebesar82,50\%, penilai ke-2 sebesar 88,75\%danpada penilai ke-3 sebesar $85,00 \%$. Rata-rata persentase dari ahli mediadiatas sebesar 87,08\%.Dari persentase kelayakan media pembelajaran uji media dapat diketahui bahwa media pembelajaran termasuk dalam kategori sangat baik.

2. Hasil perhitungan kelayakan oleh ahli materi.

Tabel 3. Hasil Perhitungan Kelayakan oleh Ahli Materi

\begin{tabular}{|c|c|c|c|c|c|}
\hline No & Penilai & $\begin{array}{c}\text { Jumlah } \\
\text { skor }\end{array}$ & $\begin{array}{c}\text { Skor yang } \\
\text { diharapakan }\end{array}$ & $\begin{array}{c}\text { Persentase } \\
\text { Rata-rata }\end{array}$ & Kategori \\
\hline 1. & Penilai ke-1 & 37 & 45 & $82,22 \%$ & Sangat Baik \\
\hline 2. & Penilai ke-2 & 41 & 45 & $91,11 \%$ & Sangat Baik \\
\hline \multicolumn{2}{|c|}{ Jumlah } & 78 & 90 & $86,67 \%$ & Sangat Baik \\
\hline
\end{tabular}

Dari Tabel 3 terlihat bahwa presentase kelayakan oleh ahli materi yaitu pada penilai ke-1 sebesar 82,22\%dan pada Penilai ke-2 sebesar 91,11\%. Rata-rata persentase dari ahli materi diatas sebesar 86,67\%. Dari persentase kelayakan media pembelajaran uji materi dapat diketahui bahwa media pembelajaran termasuk dalam kategori sangatbaik.

3. Hasil perhitungan kelayakan oleh siswa.

Tabel 4. Hasil Perhitungan Kelayakan oleh Siswa

\begin{tabular}{|l|c|c|c|c|c|}
\hline No & Penilai & $\begin{array}{c}\text { Jumlah } \\
\text { skor }\end{array}$ & $\begin{array}{c}\text { Skor yang } \\
\text { diharapakan }\end{array}$ & $\begin{array}{c}\text { Persentase } \\
\text { Rata-rata }\end{array}$ & Kategori \\
\hline 1. & Uji I & 1649 & 2025 & $81,43 \%$ & Sangat Baik \\
\hline 2. & Uji II & 2179 & 2550 & $85,45 \%$ & Sangat Baik \\
\hline \multicolumn{2}{|c|}{ Jumlah } & 3828 & 4575 & $83,67 \%$ & Sangat Baik \\
\hline
\end{tabular}

Dari Tabel 4 terlihat bahwa presentase kelayakan media oleh siswa yaitu pada uji I sebesar $81.43 \%$ dan ada uji II sebesar $85.45 \%$.Rata-rata persentase dari kedua uji 
I dan uji II diatas sebesar 83.67\%.Dari persentase kelayakan media pembelajaran uji materi dapat diketahui bahwa media pembelajaran termasuk dalam kategori sangatbaik.

\section{Kesimpulan}

Berdasarkan hasil penelitian dan pembahasan, diperoleh kesimpulan sebagai berikut:

1. Media yang dihasilkan berupa CD pembelajaran matematika yang didalamnya membahas materi pertidaksamaan satu variabel. CD pembelajaran ini dikembangakan dengan menggunakan model pengembangan yang direvisi berdasarkan saran dan masukan dari dosen pembimbing, ahli media, ahli materi, dan siswa.

2. Hasil uji kelayakan media pembelajaran matematika oleh ahli media sebesar $87,08 \%$ dengan kategori sangat baik. Uji kelayakan oleh ahli materi sebesar86,67\% dengan kategori sangat baik.

3. Hasil uji kelayakan media pembelajaran matematika oleh siswa sebanyak 61 siswa sebesar 83,67\% dengan kategori sangat baik. Dari persentase kelayakan media pembelajaran diketahui bahwa media pembelajaran termasuk dalam kategori sangat baik sehingga layak digunakan sebagai media pembelajaran.

Sehingga diharapkan guru dapat memanfaatkannya dan menggunakannya dalam proses belajar mengajar, siswa juga dapat menggunakannya sebagai sumber belajar mandiri sehingga diharapkan dapat meningkatkan motivasi dan hasil belajar matematika.

\section{Pustaka}

Arsyad, Azhar. (2010). Media Pembelajaran. Jakarta: PT. RajaGrafindo Persada.

Baharuddin. (2007). Teori Belajar \& Pembelajaran. Yogyakarta: ar-Ruzz Media.

Cagara, Hafied. (2014). Pengantar Ilmu Komunikasi (Edisi Kedua). Jakarta: PT. RajaGrafindo Persada.

Daryanto, (2011). Media Pembelajaran. Bandung: PT. SARANA TUTORIAL NURANI SEJAHTERA.

Istiqlal, Muhammad. (2011). Pengembangan Media Pembelajaran Berbasis Multimedia Interaktif Menggunakan Adobe Flash CS.3 Dalam Pembelajaran Matematika Pada Siswa Kelas X Semester 1 Standart Kompetensi Sistem Pertidaksamaan Satu Variabel. Yogyakarta: UIN Sunan Kalijaga.

Krisna. (2009). "Pengertian dan Ciri-ciri Pembelajaran". http://krisna1.blog.uns.ac.id/2009/10/19/pengertian-dan-ciri-ciripembelajaran/, diunduh tanggal 22 desember 2011 jam 12:24.

Nurina, Hidayah. (2011). Pengembangan Media Pembelajaran Matematika Interaktif Dengan Aplikasi Macromedia Flash 8 Pada Pokok Bahasan Bangun Ruang 
Sisi Datar di SMP Kelas VIII Bilingual. Yogyakarta: Universitas Ahmad Dahlan.

Prasetyo, Fransiskus Hadi. (2007). Desain dan Aplikasi Media Pembelajaran dengan Menggunakan Flash MX. Yogyakarta: ARDANA MEDIA.

Rahardjo, Mudjia. (2011). "Peringkat Pendidikan Indonesia Menurun". Mudjiarahardjo.com/artikel/315-peringkat-pendidikan-indonesia-menurun html. diunduh tanggal 7 April 2012 jam 08: 00.

Setijo, Ade. (2010). "Adobe Flash: vektor-animasi-swf". http://dotcomcell.com/kumpulan-artikel/2010/11/adobe-flash-vektor-animasiswf.html. diunduh tanggal 21 desember 2011 jam 10:48.

Sudijono, Anas. (2011). Pengantar Evaluasi Pendidikan. Jakarta: PT. RajaGrafindo Persada.

Sadiman, Arief S. (2007). Media Pendidikan Pengertian, Pengembangan, dan Pemanfaatnya. Jakarta: PT. RajaGrafindo Persada.

Sugiyono, (2011). Metode Penelitian Pendidikan Pendekatan Kuantitatif, Kualitatif, dan $R \& D$. Bandung: Alfabeta.

Unikaja.com. (2011). "Wow, Indonesia Juara Umum Olimpiade Matematika". www.unikaja.com/2011/10/wow-indonesia-juara-umum-olimpiade.html. diunduh tanggal 22 Desember 2011 jam 13:25.

Wikipedia. (2011). "Komputer”. http://id.wikipedia.org/wiki/Komputer. diunduh tanggal 21 Desember 2011 jam 10:31. 